\title{
The destiny of $\mathrm{Ca}^{2+}$ released by mitochondria
}

\author{
Ayako Takeuchi $\cdot$ Bongju Kim $\cdot$ Satoshi Matsuoka
}

Received: 27 March 2014 / Accepted: 9 June 2014/Published online: 4 July 2014

(C) The Author(s) 2014. This article is published with open access at Springerlink.com

\begin{abstract}
Mitochondrial $\mathrm{Ca}^{2+}$ is known to regulate diverse cellular functions, for example energy production and cell death, by modulating mitochondrial dehydrogenases, inducing production of reactive oxygen species, and opening mitochondrial permeability transition pores. In addition to the action of $\mathrm{Ca}^{2+}$ within mitochondria, $\mathrm{Ca}^{2+}$ released from mitochondria is also important in a variety of cellular functions. In the last 5 years, the molecules responsible for mitochondrial $\mathrm{Ca}^{2+}$ dynamics have been identified: a mitochondrial $\mathrm{Ca}^{2+}$ uniporter (MCU), a mitochondrial $\mathrm{Na}^{+}-\mathrm{Ca}^{2+}$ exchanger (NCLX), and a candidate for a mitochondrial $\mathrm{H}^{+}-\mathrm{Ca}^{2+}$ exchanger (Letm1). In this review, we focus on the mitochondrial $\mathrm{Ca}^{2+}$ release system, and discuss its physiological and pathophysiological significance. Accumulating evidence suggests that the mitochondrial $\mathrm{Ca}^{2+}$ release system is not only crucial in maintaining mitochondrial $\mathrm{Ca}^{2+}$ homeostasis but also participates in the $\mathrm{Ca}^{2+}$ crosstalk between mitochondria and the plasma membrane and between mitochondria and the endoplasmic/sarcoplasmic reticulum.
\end{abstract}

Keywords Mitochondria $\cdot \mathrm{Ca}^{2+}$ dynamics $\cdot \mathrm{NCLX}$. Letm1 - Cellular function

\footnotetext{
A. Takeuchi $(\bowtie) \cdot S$. Matsuoka

Department of Integrative and Systems Physiology, Faculty

of Medical Sciences, University of Fukui, 23-3,

Matsuokashimoaizuki, Eiheiji-cho, Yoshida-gun,

Fukui 910-1193, Japan

e-mail: atakeuti@u-fukui.ac.jp

B. Kim

Division of Experimental Immunology, Institute for Genome

Research, University of Tokushima, 3-18-15, Kuramoto,

Tokushima 770-8503, Japan
}

\section{Introduction}

Mitochondria are crucial organelles in ATP production as well as in $\mathrm{Ca}^{2+}$ storage. They also serve as master switches determining cell fate on exposure to different stimuli [1-3]. Mechanisms of $\mathrm{Ca}^{2+}$ homeostasis in mitochondria have been extensively studied over the last half century, so the importance of mitochondrial $\mathrm{Ca}^{2+}$ in regulating mitochondrial functions is well recognized. $\mathrm{Ca}^{2+}$ enters mitochondria mainly via a mitochondrial $\mathrm{Ca}^{2+}$ uniporter, a protein known as MCU or CCDC109A [4, 5]. The characteristics and physiological and pathophysiological functions of this protein, and its associated proteins have been widely studied [6-8]. On the other hand, studies of the molecules responsible for $\mathrm{Ca}^{2+}$ release by mitochondria have just begun, although functional characterization of the release system started in the 1970s [9]. The mitochondrial $\mathrm{Ca}^{2+}$ release system mainly consists of an $\mathrm{Na}^{+}-\mathrm{Ca}^{2+}$ exchanger and an $\mathrm{H}^{+}-\mathrm{Ca}^{2+}$ exchanger. The molecule responsible for the former (NCLX) was identified in 2010 [10]. A possible molecular candidate for the latter (Letm1) was reported in 2009 [11], although this is still controversial.

It is now well understood that some mitochondria are in close contact with the plasma membrane and others with the endoplasmic reticulum (ER)/sarcoplasmic reticulum (SR). Although the molecular mechanisms of tethering of mitochondria to the plasma membrane are not well understood, several tethering protein complexes involved in interactions between mitochondria and the ER/SR have been identified, and details of the molecular mechanisms have been reviewed $[12,13]$. It is believed that these interactions are important in modulating a variety of cellular functions.

In this paper we review recent progress in the study of mitochondrial $\mathrm{Ca}^{2+}$ release system, specifically, interactions between mitochondria and the ER/SR and 
interactions between mitochondria and the plasma membrane, and discuss their physiological and pathophysiological significance, focusing on the destiny of $\mathrm{Ca}^{2+}$ released by mitochondria.

\section{Physiological roles of $\mathrm{Ca}^{2+}$ in mitochondria and released by mitochondria}

Mitochondrial $\mathrm{Ca}^{2+}$ regulates diverse cellular functions

It is now well accepted that mitochondrial $\mathrm{Ca}^{2+}$ is important in regulation of diverse cellular functions (Fig. 1). For example, an increase of mitochondrial $\mathrm{Ca}^{2+}$ activates three dehydrogenases in the mitochondrial matrix: pyruvate dehydrogenase, oxoglutarate dehydrogenase, and isocitrate dehydrogenase. As a result, the mitochondrial NADH-to-NAD ratio increases and, hence, flow of electrons down the respiratory chain increases, adjusting ATP synthesis to the increased ATP needs of a cell [1416]. Mitochondrial $\mathrm{Ca}^{2+}$-mediated NADH oxidase activation may result in increased production of mitochondrial reactive oxygen species (ROS). In fact, an increase of mitochondrial $\mathrm{Ca}^{2+}$ has been reported to increase production of ROS in the heart and in neurons, resulting in impaired respiration and in cytotoxicity [17, 18]. Several studies have indicated that $\mathrm{Ca}^{2+}$ activates F1-Fo ATP synthase, balancing ATP utilization increased by $\mathrm{Ca}^{2+}$, and that it is probably the intra-mitochondrial $\mathrm{Ca}^{2+}$ which regulates F1-Fo ATP synthase, although this is still controversial $[19,20]$. A large increase of mitochondrial $\mathrm{Ca}^{2+}$ results in opening of a non-specific pore called the mitochondrial permeability transition pore (PTP). PTP opening is followed by inner mitochondrial membrane depolarization, uncoupling of oxidative phosphorylation, and massive mitochondrial swelling, resulting in necrosis [1, 21-23]. PTP is also involved in apoptosis. Apoptosis-promoting factors, for example cytochrome c and pro-caspases, are released to the cytosol through PTP [24-26]. Furthermore, cardiac mitochondrial nitric oxide (NO) synthase is activated by mitochondrial $\mathrm{Ca}^{2+}$, contributing to NO-mediated cardioprotection against PTP opening [27]. Accordingly, mitochondrial $\mathrm{Ca}^{2+}$ is crucial in tuning a variety of mitochondrial and, thus, cellular functions.

What is the source of the mitochondrial $\mathrm{Ca}^{2+}$ ? The location of the mitochondria within the cell seems important for mitochondrial $\mathrm{Ca}^{2+}$ uptake. Some mitochondria are located in proximity to the plasma membrane or the ER/ SR. $\mathrm{Ca}^{2+}$ flowing through the plasma membrane or released from the ER/SR predominantly enters neighbouring mitochondria. In other words, there is $\mathrm{Ca}^{2+}$ crosstalk between mitochondria and the plasma membrane and between mitochondria and the ER/SR (Fig. 2). A

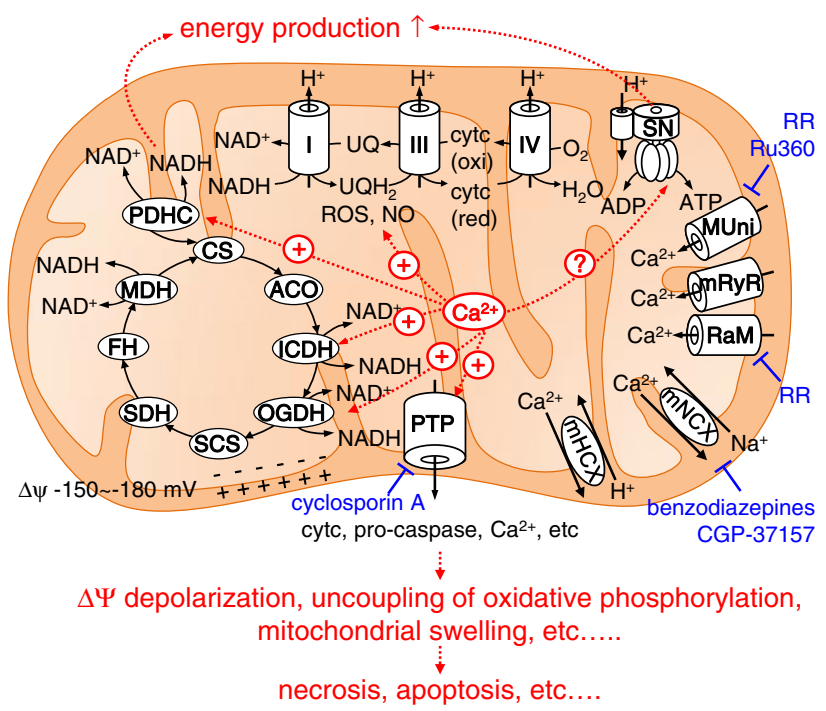

Fig. 1 Regulation of mitochondrial functions by mitochondrial $\mathrm{Ca}^{2+}$ Mitochondrial $\mathrm{Ca}^{2+}$ activates three dehydrogenases in the mitochondrial matrix: pyruvate dehydrogenase (PDHC), oxoglutarate dehydrogenase (OGDH), and isocitrate dehydrogenase (ICDH). ROS production is stimulated by increased mitochondrial $\mathrm{Ca}^{2+}$, possibly via increased NADH production. F1-Fo ATP synthase is activated by mitochondrial $\mathrm{Ca}^{2+}$, although this is still controversial. This regulatory activity contributes to energy homeostasis. PTP opening is activated by a large increase of mitochondrial $\mathrm{Ca}^{2+}$, resulting in the release of a variety of compounds from mitochondria, for example cytochrome c (cytc), pro-caspase, and $\mathrm{Ca}^{2+}$, leading to apoptosis or necrosis. $C S$ citrate synthase, ACO aconitase, SCS succinyl-CoA synthase, $S D H$ succinate dehydrogenase, $F H$ fumarate hydratase, $M D H$ malate dehydrogenase, $S N$ F1-Fo ATP synthase, $R R$ ruthenium red, MUni mitochondrial $\mathrm{Ca}^{2+}$ uniporter, $m R y R$ mitochondrial RyR, $m N C X$ mitochondrial $\mathrm{Na}^{+}-\mathrm{Ca}^{2+}$ exchanger, $m H C X$ mitochondrial $\mathrm{H}^{+}-\mathrm{Ca}^{2+}$ exchanger

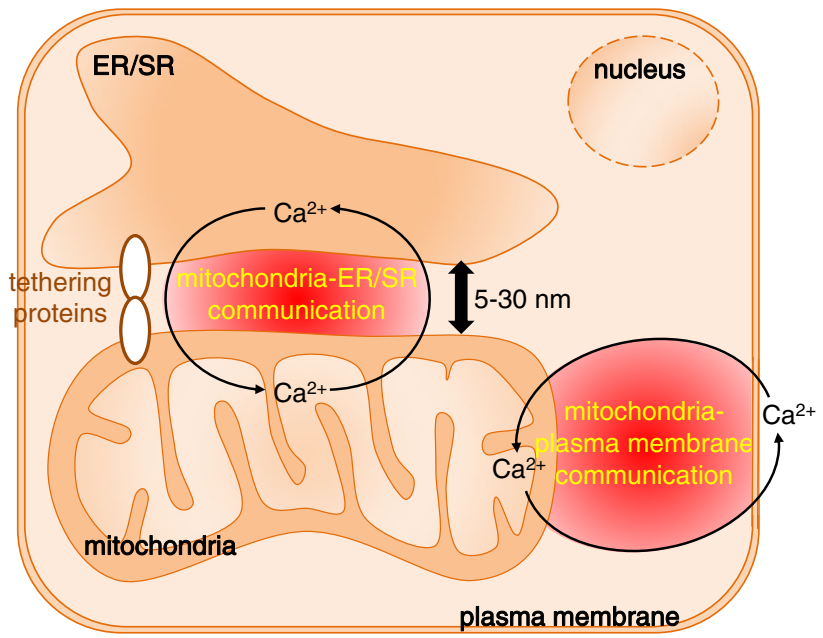

Fig. $2 \mathrm{Ca}^{2+}$ communication between mitochondria and the plasma membrane and between mitochondria and the ER/SR

substantial amount of the $\mathrm{Ca}^{2+}$ flowing through the plasma membrane or released by the ER/SR binds to cytosolic soluble $\mathrm{Ca}^{2+}$-binding proteins, for example calmodulin, 
troponin $\mathrm{C}$, and calbindin. Of these, calmodulin is a ubiquitous protein well conserved across eukaryotes and $\mathrm{Ca}^{2+}$-bound calmodulin regulates a variety of cellular functions by binding to calmodulin-dependent kinase, calcineurin, plasma membrane $\mathrm{Ca}^{2+}$ ATPase, and the ryanodine receptor, among others [28]. Further information about these $\mathrm{Ca}^{2+}$-buffering proteins is available in a detailed review [29].

$\mathrm{Ca}^{2+}$ crosstalk between mitochondria and the plasma membrane and between mitochondria and the ER/SR

$\mathrm{Ca}^{2+}$ enters cells via $\mathrm{Ca}^{2+}$ channels in the plasma membrane, for example the voltage-gated $\mathrm{Ca}^{2+}$ channel (VDCC) and the $\mathrm{Ca}^{2+}$ release-activated $\mathrm{Ca}^{2+}$ channel (CRAC) or store-operated $\mathrm{Ca}^{2+}$ channel. The $\mathrm{Ca}^{2+}$ which enters the cell is efficiently taken up by mitochondria located near the plasma membrane [30-33]. Lawrie et al. [30] found that after depletion of stored $\mathrm{Ca}^{2+}$, re-addition of extracellular $\mathrm{Ca}^{2+}$ evoked an increase in mitochondrial $\mathrm{Ca}^{2+}$ but not in cytoplasmic $\mathrm{Ca}^{2+}$ in human umbilical vein endothelial cell line ECV304, in which $14 \%$ of mitochondria are located within $700 \mathrm{~nm}$ of the inner surface of the plasma membrane. They suggested that $\mathrm{Ca}^{2+}$ levels increase in microdomains beneath the plasma membrane, causing predominant $\mathrm{Ca}^{2+}$ uptake by mitochondria facing the microdomains. However, the contribution of the $\mathrm{Ca}^{2+}$ microdomains depends on cell type, because this phenomenon was not observed for a clone of a HeLa cell line, in which $<6 \%$ of mitochondria are located in the proximity of the plasma membrane. Park et al. [32] reported that store-operated $\mathrm{Ca}^{2+}$ influx via CRAC channels through the basolateral membrane led to predominant $\mathrm{Ca}^{2+}$ uptake by sub-plasmalemmal mitochondria in pancreatic acinar cells. These reports suggest $\mathrm{Ca}^{2+}$ communication, through plasma membrane $\mathrm{Ca}^{2+}$ channels, with mitochondria located in proximity to plasma membrane. $\mathrm{Ca}^{2+}$ communication in the opposite direction has also been suggested. Mitochondrial membrane depolarization suppressed store-operated $\mathrm{Ca}^{2+}$ entry in $\mathrm{T}$ lymphocytes and in rat basophilic leukaemia cells [34, 35]. Accordingly, bidirectional $\mathrm{Ca}^{2+}$ crosstalk between mitochondria and the plasma membrane is important in the regulation of cellular functions. As will be described below, the mitochondrial $\mathrm{Na}^{+}-\mathrm{Ca}^{2+}$ exchanger NCLX is involved in this $\mathrm{Ca}^{2+}$ crosstalk.

The ER/SR is major $\mathrm{Ca}^{2+}$ store within the cells. The ER/SR is located close to mitochondria, approximately 5-30 nm, and narrow interorganellar spaces exist between the organelles in a variety of cell types, including B lymphocytes and cardiomyocytes [36]. Figure 3 shows 3D-reconstructed confocal images of mitochondria and the ER/SR of cultured B lymphocytes and cardiomyocytes. The two organelles are located close to each other, although narrow interorganellar spaces are not visible. The close contact between mitochondria and the $\mathrm{ER} / \mathrm{SR}$ is supported by tethering proteins, for example MIRO, DRP1, MFN2, and Mmm1/Mdm10/Mdm12/ Mdm34 complex [12, 13]. Mitochondria-ER/SR communication is important for regulation of a variety of cellular processes, including lipid biosynthesis, mitochondrial division, and $\mathrm{Ca}^{2+}$ signalling $[12,37]$. With regard to $\mathrm{Ca}^{2+}$, these narrow interorganellar spaces may serve to create $\mathrm{Ca}^{2+}$ level much higher than in the bulk cytosol, up to $9-50 \mu \mathrm{M}[38,39]$, enabling the mitochondrial $\mathrm{Ca}^{2+}$ uniporter, the $\mathrm{Ca}^{2+}$ affinity of which is relatively low, to transport enough $\mathrm{Ca}^{2+}$ into mitochondria. Several studies reported that an inositol 1,4,5-trisphosphate $\left(\mathrm{IP}_{3}\right)$ receptor of the ER and a voltagedependent anion channel of the outer mitochondrial membrane are located in the mitochondria-ER region, creating a $\mathrm{Ca}^{2+}$ pathway from the ER to the mitochondria. This may aid regulation of energy metabolism and apoptosis in such cells as HeLa cells, CHO cells, fibroblasts, and yeast [40-42]. $\mathrm{Ca}^{2+}$ released from the ryanodine receptor (RyR) on the SR also accumulates in mitochondria of rat ventricular myocytes, indicating preferential coupling of $\mathrm{Ca}^{2+}$ transport from the SR to mitochondria [38]. It has been suggested that reverse $\mathrm{Ca}^{2+}$ movement, from mitochondria to the ER/SR, is important for refilling ER/SR $\mathrm{Ca}^{2+}$ after ligand stimulation of such cells as HeLa cells, endothelial cell line, and vascular smooth muscle cells, to minimize cytosolic $\mathrm{Ca}^{2+}$ elevation and to prevent depletion of ER/SR $\mathrm{Ca}^{2+}[43-$ 45]. The crucial importance of NCLX in the movement of $\mathrm{Ca}^{2+}$ from mitochondria to the ER/SR was clearly demonstrated in our recent studies [46-48], as described below. The bidirectional $\mathrm{Ca}^{2+}$ crosstalk between mitochondria and the ER/SR is also important for regulating cellular functions.

Taken together, $\mathrm{Ca}^{2+}$ crosstalk between mitochondria and the plasma membrane and between mitochondria and the ER/SR is important in controlling cellular functions. Understanding the roles of each molecule participating in the $\mathrm{Ca}^{2+}$ crosstalk is particularly important for fully understanding cellular physiological and pathophysiological functions.

\section{$\mathrm{Ca}^{2+}$-transporting systems in mitochondria}

Studies of mitochondrial $\mathrm{Ca}^{2+}$ dynamics started more than half a century ago. The existence of a respiration-dependent pathway of $\mathrm{Ca}^{2+}$ into isolated rat kidney mitochondria was reported in the early 1960s $[49,50]$. In the 1970s, pathways of $\mathrm{Ca}^{2+}$ out of isolated rat heart mitochondria 
Fig. 3 Close location of mitochondria and the ER/SR in A20 B lymphocytes (a) and in HL-1 cardomyocytes (b). Cells were co-transfected with mitochondria-targeted pTagRFP-mito (red) and ER/ SR-targeted cameleon D1ER (green). Images were acquired by use of a laser-scanning confocal microscope (LSM710, Carl Zeiss) with a $\times 63$ oil objective lens, and 3D images were reconstructed by use of Imaris (Bitplane) (color figure online)
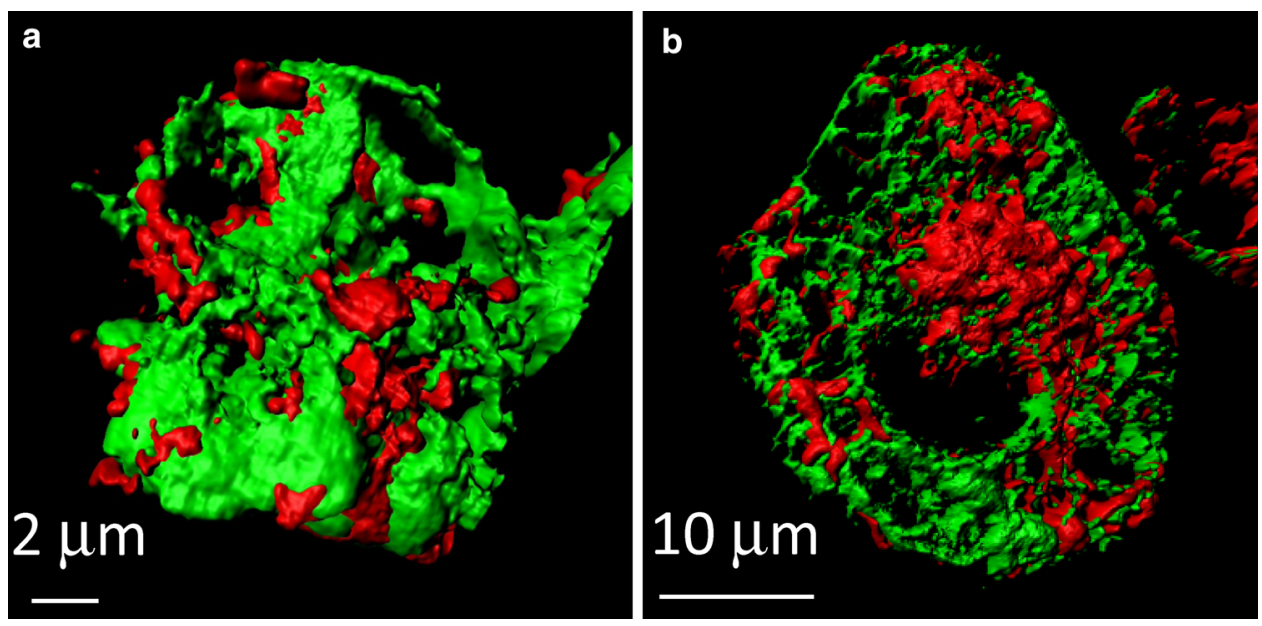

$\left(\mathrm{Na}^{+}\right.$-dependent) and out of isolated rat liver mitochondria $\left(\mathrm{Na}^{+}\right.$-independent and $\mathrm{H}^{+}$-dependent) were discovered [9, 51]. Since then, characteristics of mitochondrial $\mathrm{Ca}^{2+}$ dynamics have been extensively studied [1, 52-54].

The major pathways of $\mathrm{Ca}^{2+}$ uptake into and efflux out of mitochondria are summarized in Fig. $1 . \mathrm{Ca}^{2+}$ uptake into mitochondria is mainly mediated by a mitochondrial $\mathrm{Ca}^{2+}$ uniporter driven by a highly negative membrane potential (mitochondrial membrane potential $\Delta \Psi$ is -150 to $-180 \mathrm{mV}$ ) [55]. Another uptake system is a rapid uptake mode (RaM) which might contribute to mitochondrial $\mathrm{Ca}^{2+}$ uptake from fast cytosolic $\mathrm{Ca}^{2+}$ transients. A mitochondrial ryanodine receptor is also reported to mediate $\mathrm{Ca}^{2+}$ uptake into rat heart mitochondria. Details are available in other reviews $[1,52]$. It was not until the 2010 s that the identities of the molecules responsible for the mitochondrial $\mathrm{Ca}^{2+}$ uniport were revealed. A regulator of the $\mathrm{Ca}^{2+}$ uniporter, MICU, was discovered in 2010 before cloning of the mitochondrial $\mathrm{Ca}^{2+}$ uniporter [56]. MCU (or CCDC109A) was then discovered as a gene coding the mitochondrial $\mathrm{Ca}^{2+}$ uniporter [4, 5]. Very recently, characteristics of MCU knockout have been reported. Although MCU knockout in Trypanosoma brucei resulted in marked dysregulation of mitochondrial bioenergetics, causing autophagy and cell death [57], relatively minor alteration of basal energetics was observed for MCU knockout mice [58]. MCU and its regulators have been reviewed in detail elsewhere $[7,8]$.

$\mathrm{Ca}^{2+}$ efflux from mitochondria is mainly mediated by two saturable pathways, an $\mathrm{Na}^{+}$-dependent $\left(\mathrm{Na}^{+}-\mathrm{Ca}^{2+}\right.$ exchanger; benzodiazepines and CGP-37157-sensitive) pathway and an $\mathrm{Na}^{+}$-independent $\left(\mathrm{H}^{+}-\mathrm{Ca}^{2+}\right.$ exchanger; ruthenium red-insensitive) pathway. Under pathophysiological conditions in which the PTP opens, PTP functions as a $\mathrm{Ca}^{2+}$ transporter from mitochondria. In the sections below we describe, in detail, the two physiological pathways of mitochondrial $\mathrm{Ca}^{2+}$ release.
Mitochondrial $\mathrm{Na}^{+}-\mathrm{Ca}^{2+}$ exchanger

Biophysical properties of the mitochondrial $\mathrm{Na}^{+}-\mathrm{Ca}^{2+}$ exchanger

The mitochondrial $\mathrm{Na}^{+}-\mathrm{Ca}^{2+}$ exchanger was first discovered by Carafoli et al. [9] in 1974 in isolated rat heart mitochondria. This $\mathrm{Na}^{+}-\mathrm{Ca}^{2+}$ exchange activity is found in a wide variety of tissues and is dominant in the heart, brain, skeletal muscle, parotid gland, adrenal cortex, and brown fat $[52,59]$. The $\mathrm{Na}^{+}-\mathrm{Ca}^{2+}$ exchanger is also present in liver, kidney, and lung mitochondria, although its activity is weak [60]. In tissues in which mitochondrial $\mathrm{Na}^{+}-\mathrm{Ca}^{2+}$ exchange activity is low, $\mathrm{H}^{+}-\mathrm{Ca}^{2+}$ exchange activity is of dominant importance in the release of $\mathrm{Ca}^{2+}$ from mitochondria [61].

One interesting characteristic of the mitochondrial $\mathrm{Na}^{+}-$ $\mathrm{Ca}^{2+}$ exchanger, which is distinct from the plasmalemmal $\mathrm{Na}^{+}-\mathrm{Ca}^{2+}$ exchanger (NCX), is that $\mathrm{Li}^{+}$can substitute for $\mathrm{Na}^{+}$[9]. This unique characteristic contributed to identification of NCLX, a gene responsible for the mitochondrial $\mathrm{Na}^{+}-\mathrm{Ca}^{2+}$ exchanger, as will be described in the next section. The stoichiometry (ion-exchange ratio) and the electrogenicity of the mitochondrial $\mathrm{Na}^{+}-\mathrm{Ca}^{2+}$ exchanger were controversial, but it was believed to be electroneutral $[62,63]$. Our group clearly demonstrated, by use of permeabilized rat ventricular myocytes, that the mitochondrial $\mathrm{Na}^{+}-\mathrm{Ca}^{2+}$ exchanger is voltage-dependent and electrogenic, which suggests the stoichiometry is $>3 \mathrm{Na}^{+}$for one $\mathrm{Ca}^{2+}[64]$. We also predicted by computer simulation that the voltage dependence of the mitochondrial $\mathrm{Na}^{+}-\mathrm{Ca}^{2+}$ exchanger changes, the affinity becoming lower with mitochondrial membrane depolarization [64]. Because of these features, the mitochondrial $\mathrm{Na}^{+}-\mathrm{Ca}^{2+}$ exchanger dynamically changes the exchange mode (forward or reverse) and modulates the mitochondrial $\mathrm{Ca}^{2+}$ 
concentration in a manner dependent on cytosolic $\mathrm{Na}^{+}$ concentration and mitochondrial membrane potential. Recently, several molecules which may modulate the mitochondrial $\mathrm{Na}^{+}-\mathrm{Ca}^{2+}$ exchanger have been identified. Gandhi et al. [18] reported that a deficiency of a PINK1, a 581-amino-acid protein consisting of a mitochondrial targeting motif and a serine/threonine kinase domain homologous with that of the $\mathrm{Ca}^{2+} /$ calmodulin family, causes impairment of mitochondrial $\mathrm{Ca}^{2+}$ efflux via the mitochondrial $\mathrm{Na}^{+}-\mathrm{Ca}^{2+}$ exchanger. Mutations in the PINK1 gene are known to cause autosomal recessive Parkinson's disease [18]. Da Cruz et al. [65] showed that a stomatinlike protein 2 (SLP-2), a novel member of the stomatin superfamily found in several types of human tumour, negatively modulates mitochondrial $\mathrm{Na}^{+}-\mathrm{Ca}^{2+}$ exchange activity in HeLa cells, regulating the capacity of mitochondria to store $\mathrm{Ca}^{2+}$. Although detailed mechanisms underlying the regulation of mitochondrial $\mathrm{Na}^{+}-\mathrm{Ca}^{2+}$ exchange activity by these proteins have not yet been clarified, recent identification of NCLX as a mitochondrial $\mathrm{Na}^{+}-\mathrm{Ca}^{2+}$ exchanger will surely accelerate understanding of the mechanisms.

\section{Cloning, tissue distribution, and cellular localization of NCLX}

In 2004, two independent research groups reported the cloning of a new transporter mediating $\mathrm{Na}^{+}-\mathrm{Ca}^{2+}$ exchange, which was subsequently identified as a mitochondrial $\mathrm{Na}^{+}-\mathrm{Ca}^{2+}$ exchanger $[66,67]$. Cai and Lytton employed a bioinformatics-based search of the GenBank ${ }^{\mathrm{TM}}$ database using a conserved amino acid sequence of the $\alpha$ repeat regions of the $\mathrm{K}^{+}$-dependent $\mathrm{Na}^{+}-\mathrm{Ca}^{2+}$ exchanger (NCKX) gene family 2 (NCKX2) [66]. The amino acid sequence of the identified clone was divergent from that of NCX and NCKX family members, but was slightly closer to that of NCKX. The clone was therefore named "NCKX6". They also found an alternative spliced isoform of mouse NCKX6. Although the long isoform was retained in the ER fraction and was not functional when heterologously expressed in HEK293 cells, the short isoform was targeted in the plasma membrane and had $\mathrm{K}^{+}$-dependent $\mathrm{Na}^{+}-\mathrm{Ca}^{2+}$ exchange activity. Very soon after the publication by Cai and Lytton [66], Sekler's group found the same clone during a search for the $\mathrm{Na}^{+}-\mathrm{Zn}^{2+}$ exchanger gene [67]. In contrast with the report by Cai and Lytton [66], both long and short clones had $\mathrm{K}^{+}$-independent $\mathrm{Na}^{+}-$ $\mathrm{Ca}^{2+}$ exchange activity and $\operatorname{did}$ not have $\mathrm{Na}^{+}-\mathrm{Zn}^{2+}$ exchange activity when heterologously expressed in HEK293 cells. They also found that $\mathrm{Li}^{+}$can substitute for $\mathrm{Na}^{+}$to release $\mathrm{Ca}^{2+}$ from the cells, so they named the clone "NCLX". The discrepant results obtained by the two groups might be a result of different experimental conditions, i.e. Cai and Lytton [66] used $\mathrm{Li}^{+}$as substituent for $\mathrm{Na}^{+}$to examine $\mathrm{K}^{+}$-dependent $\mathrm{Na}^{+}-\mathrm{Ca}^{2+}$ exchange activity. This might have affected the responsiveness of the clone. In addition, FLAG epitope might have interfered with the sorting system in the Cai and Lytton [66] experiments. Anyway, both groups found that NCKX6/NCLX had $\mathrm{Na}^{+}-\mathrm{Ca}^{2+}$ exchange activity and broad tissue distribution, for example heart, pancreas, skeletal muscle, stomach, spleen, and brain.

It took another 6 years, however, for Sekler's group to discover that NCKX/NCLX is the long-sought mitochondrial $\mathrm{Na}^{+}-\mathrm{Ca}^{2+}$ exchanger. In 2010, Sekler's group beautifully demonstrated that NCLX was located in mitochondria and its characteristics corresponded well to those of the mitochondrial $\mathrm{Na}^{+}-\mathrm{Ca}^{2+}$ exchanger [10]. Direct measurements of mitochondrial $\mathrm{Ca}^{2+}$ by use of the mitochondria-targeted $\mathrm{Ca}^{2+}$ sensing protein Pericam-mito [68] clearly showed that $\mathrm{Ca}^{2+}$ efflux from mitochondria was accelerated by overexpressing NCLX in an $\mathrm{Na}^{+}$and $\mathrm{Li}^{+}$-dependent manner and was decelerated by knocking down NCLX. The fact that $\mathrm{Li}^{+}$can substitute for $\mathrm{Na}^{+}$in releasing $\mathrm{Ca}^{2+}$ from mitochondria corresponds well to the unique characteristic of mitochondrial $\mathrm{Na}^{+}-\mathrm{Ca}^{2+}$ exchange. This NCLX-mediated $\mathrm{Ca}^{2+}$ efflux from mitochondria was inhibited by the mitochondrial $\mathrm{Na}^{+}-\mathrm{Ca}^{2+}$ exchange inhibitor CGP-37157. It was also shown that mitochondrial $\mathrm{Na}^{+}$, measured by use of the mitochondrial $\mathrm{Na}^{+}$-sensing dye CoroNa Red, increased during the mitochondrial $\mathrm{Ca}^{2+}$ efflux phase, and the rate became much faster with NCLX overexpression. These results confirm that NCLX is the gene responsible for the mitochondrial $\mathrm{Na}^{+}-\mathrm{Ca}^{2+}$ exchanger. Since then, information about the involvement of NCLX in the physiological and pathophysiological functions of different types of cell has accumulated. We will describe, in detail, recent findings on the roles of NCLX in pancreatic $\beta$-cells, astrocytes, B lymphocytes, and cardiomyocytes. Experimental results from NCLX knockout/knockdown in each type of cell are summarized in Table 1.

\section{NCLX in pancreatic $\beta$-cells (Fig. 4a)}

When the plasma glucose level increases, ATP production in pancreatic $\beta$-cells increases. ATP-dependent $\mathrm{K}^{+}$channels consequently close, resulting in depolarization of the plasma membrane. Subsequently, voltage-gated $\mathrm{Ca}^{2+}$ channels open, causing $\mathrm{Ca}^{2+}$ influx into the cell, and exocytosis of insulin granules occurs [69]. In addition to the metabolic roles of mitochondria in the regulation of insulin secretion [70, 71], Tarasov et al. and Nita et al. [72, 73] demonstrated the contribution of NCLX to the function of pancreatic $\beta$-cells by use of the pancreatic $\beta$ cell line MIN6 and mouse pancreatic primary $\beta$-cells. By use of 
Table 1 Effects of NCLX reduction on cellular functions

\begin{tabular}{|c|c|c|c|c|c|c|}
\hline & $\begin{array}{l}\text { Mitochondrial } \\
\mathrm{Ca}^{2+} \text { at rest }\end{array}$ & $\begin{array}{l}\text { Mitochondrial } \\
\mathrm{Ca}^{2+} \text { transient }\end{array}$ & Cytosolic $\mathrm{Ca}^{2+}$ transient & SOCE & ATP production & Others \\
\hline $\begin{array}{l}\text { Pancreatic } \beta \text { - } \\
\text { cells }([70,71])\end{array}$ & Increased & $\begin{array}{l}\text { Faster rise } \\
\text { slower } \\
\text { decline }\end{array}$ & Smaller & N.D. & $\begin{array}{l}\text { Unchanged at steady state. } \\
\text { Slightly accelerated during } \\
\text { stimulation }\end{array}$ & $\begin{array}{l}\text { Reduced } \\
\text { insulin } \\
\text { secretion }\end{array}$ \\
\hline Astrocytes ([77]) & Increased & $\begin{array}{l}\text { Faster rise } \\
\text { slower } \\
\text { decline }\end{array}$ & Smaller & $\begin{array}{l}\text { Smaller } \\
\text { and } \\
\text { slower }\end{array}$ & N.D. & $\begin{array}{l}\text { Reduced } \\
\text { glutamate } \\
\text { release } \\
\text { Impaired } \\
\text { wound } \\
\text { healing } \\
\text { Impaired } \\
\text { proliferation }\end{array}$ \\
\hline $\begin{array}{r}\text { B lymphocytes } \\
([44,45,84])\end{array}$ & N.D. & N.D. & $\begin{array}{l}\text { Diminished cytosolic } \mathrm{Ca}^{2+} \\
\text { increase after BCR } \\
\text { stimulation }\end{array}$ & $\begin{array}{l}\text { Smaller } \\
\text { and } \\
\text { slower }\end{array}$ & N.D. & $\begin{array}{l}\text { Increased } \\
\text { apoptosis } \\
\text { Reduced } \\
\text { chemotaxis }\end{array}$ \\
\hline $\begin{array}{c}\text { Cardiomyocytes } \\
([46,102])\end{array}$ & Increased & N.D. & Slower upstroke & N.D. & Unaffected & $\begin{array}{l}\text { Cycle length } \\
\text { prolongation }\end{array}$ \\
\hline
\end{tabular}

N.D. not determined

pericam-mito to directly sense the mitochondrial $\mathrm{Ca}^{2+}$, Nita et al. [73] found that membrane depolarization-mediated $\mathrm{Ca}^{2+}$ influx, ATP-mediated ER $\mathrm{Ca}^{2+}$ depletion, and treatment with $20 \mathrm{mM}$ glucose all caused a mitochondrial $\mathrm{Ca}^{2+}$ transient. In all cases, silencing of NCLX by use of siRNA or dominant negative mutant resulted in a more rapid increase in mitochondrial $\mathrm{Ca}^{2+}$ and slower mitochondrial $\mathrm{Ca}^{2+}$ decline. The resting mitochondrial $\mathrm{Ca}^{2+}$ level was higher in NCLX knockdown cells. These results not only suggest that NCLX functions as a mitochondrial $\mathrm{Na}^{+}-\mathrm{Ca}^{2+}$ exchanger, but also show that $\mathrm{Ca}^{2+}$ efflux via NCLX is already activated at the early phase of mitochondrial $\mathrm{Ca}^{2+}$ influx. Interestingly, silencing NCLX caused a smaller and slower cytosolic $\mathrm{Ca}^{2+}$ increase induced by membrane depolarization or by treatment with $20 \mathrm{mM}$ glucose. Furthermore, NCLX knockdown was followed by a delay in glucose-dependent insulin secretion, whereas ATP production was little affected. These results indicate that NCLX is a critical component of the $\mathrm{Ca}^{2+}$ crosstalk between mitochondria and the plasma membrane in modulation of the insulin secretion pattern. Tarasov et al. obtained results essentially similar to those of Nita et al. [73] in repetitively depolarized MIN6 cells with regard to NCLX function. In addition, Tarasov et al. [72] found that glucose-induced mitochondrial $\mathrm{Ca}^{2+}$ response and subsequent ATP/ADP increase was impaired under the glucolipotoxic conditions often observed with type 2 diabetes. Because mRNA expression levels of MCU and NCLX were unaltered, it was suggested that changes in the intracellular distribution of mitochondria [74] were involved in this altered $\mathrm{Ca}^{2+}$ dysfunction and ATP production. In 2013, Proverbio et al. [75] used a multi-step screening strategy to identify genes related to congenital hyperinsulinism, characterized by severe hypoglycaemia as a result of inappropriate insulin secretion by pancreatic $\beta$ cells. They found a mutation in the NCLX-encoding SLC24A6 gene, which results in amino acid change at position 564 from tyrosine to histidine. Because this position resides in the middle of putative transmembrane domain 12 and is conserved among a variety of species, including chimpanzee, mouse, rat, cattle, chicken, and zebrafish, it is possible that the mutation causes a functional change of NCLX. Further analysis is required to clarify how NCLX is involved in the pathophysiological condition of pancreatic $\beta$-cells.

\section{NCLX in astrocytes (Fig. 4b)}

Brain is another tissue highly expressing NCLX. Among the different kinds of cell constituting the brain, astrocytes constitute approximately half the volume. They express a large number of $\mathrm{G}$ protein-coupled receptors (GPCRs), linked to a diverse array of intracellular cascades including elevation of intracellular $\mathrm{Ca}^{2+}$. It is also well known that astrocytes release neurotransmitters called gliotransmitters, for example glutamate, ATP and D-serine, which bind to neuronal receptors to modulate synaptic transmission and activity [76, 77]. Thus astrocytes not only interact with neuronal activity but also modulate this activity via gliotransmitters. Although still controversial, several reports suggest that release of gliotransmitters by astrocytes depends on elevation of cytosolic $\mathrm{Ca}^{2+}[77,78]$. The 
Fig. 4 Roles of NCLX in pancreatic $\beta$-cells (a), astrocytes (b), B lymphocytes (c), and cardiomyocytes (d). See text for details

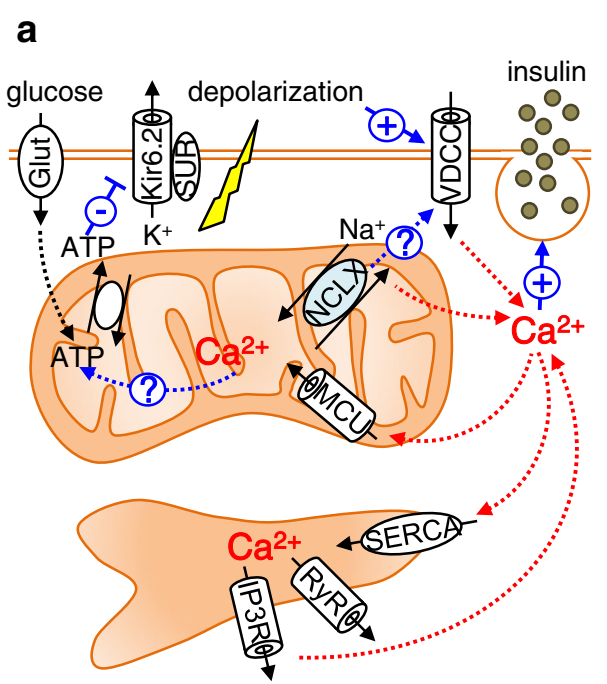

b
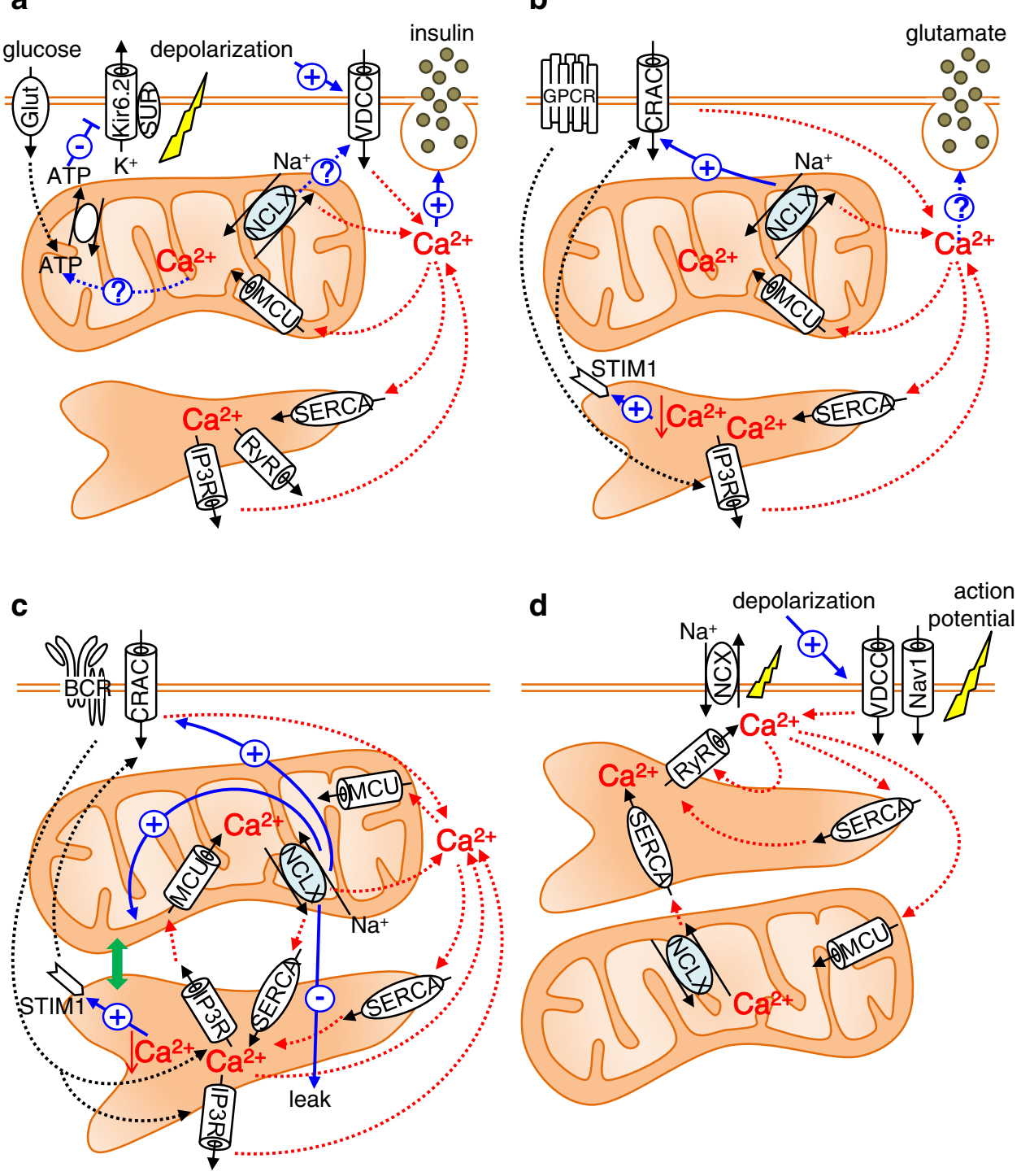

increase of cytosolic $\mathrm{Ca}^{2+}$ in astrocytes occurs via the phospholipase $\mathrm{C}(\mathrm{PLC}) / \mathrm{IP}_{3}$ pathway. That is, upon GPCR activation, PLC hydrolyses the membrane lipid phosphatidylinositol 4,5-bisphosphate to generate diacylglycerol and $I_{3}$, activating the $I_{3}$ receptor $\left(I_{3} R\right)$ and releasing $\mathrm{Ca}^{2+}$ from the ER. Parnis et al. [79], by use of a mouse astrocyte culture, examined how NCLX is involved in $\mathrm{Ca}^{2+}$ dynamics and the release of gliotransmitters. They used pericam-mito to sense mitochondrial $\mathrm{Ca}^{2+}$ and found that the resting mitochondrial $\mathrm{Ca}^{2+}$ level increased, and that the rise and decline of mitochondrial $\mathrm{Ca}^{2+}$ transients caused by extracellular ATP application became faster and slower, respectively, on knocking down NCLX. These results were very similar to those observed for pancreatic $\beta$-cells [73]. Interestingly, NCLX knockdown reduced $\mathrm{Ca}^{2+}$ entry into the cytosol both from extracellular space and from the ER, but the effect on the former was stronger.
Detailed analysis revealed that NCLX knockdown impairs store-operated $\mathrm{Ca}^{2+}$ entry (SOCE), indicative of strong $\mathrm{Ca}^{2+}$ crosstalk between mitochondria and the plasma membrane, as in pancreatic $\beta$-cells. NCLX knockdown also significantly reduced such processes as exocytotic glutamate release, in vitro wound closure, and proliferation, which may be regulated in a $\mathrm{Ca}^{2+}$-dependent manner [79].

\section{NCLX in B lymphocytes (Fig. 4c)}

Activation of B lymphocytes by antigens is followed by an increase in cytosolic $\mathrm{Ca}^{2+}$, resulting in rapid proliferation and differentiation or apoptosis, depending on the differentiation stage of the cells [80]. Upon binding of the antigen to the $\mathrm{B}$ cell surface receptor (BCR), $\mathrm{IP}_{3}$ increases and facilitates $\mathrm{Ca}^{2+}$ release from the $\mathrm{IP}_{3} \mathrm{R}$ on the ER membrane. $\mathrm{Ca}^{2+}$ release from the ER causes the initial 
cytosolic $\mathrm{Ca}^{2+}$ increase after receptor activation. Subsequent depletion of $\mathrm{Ca}^{2+}$ in the ER causes translocation of stromal interaction molecule 1 (STIM1) to the vicinity of plasmalemma, inducing a sustained and oscillatory cytosolic $\mathrm{Ca}^{2+}$ increase by activation of SOCE through CRAC channels encoded by ORAI1 $[81,82]$. We discovered that NCLX is crucial in this antigen receptor -mediated $\mathrm{Ca}^{2+}$ signalling from a combined study of mathematical simulations and NCLX knockout/knockdown in DT40 and A20 B lymphocytes [46, 47]. NCLX reduction greatly reduced cytosolic $\mathrm{Na}^{+}$-dependent mitochondrial $\mathrm{Ca}^{2+}$ efflux in saponin-permeabilized cells loaded with the mitochondrial $\mathrm{Ca}^{2+}$-sensitive dye Rhod-2, confirming that NCLX is responsible for mitochondrial $\mathrm{Na}^{+}-\mathrm{Ca}^{2+}$ exchange in $\mathrm{B}$ lymphocytes. Interestingly, mitochondrial membrane potential, evaluated by JC-1 staining, was more depolarized and DNA fragmentation (sub G1) was increased in NCLX knockout cells, suggesting that the progress of apoptosis was accelerated in NCLX knockout cells. Mathematical model revealed that NCLX inhibition reduces basal ER $\mathrm{Ca}^{2+}$ content and suppresses BCR-mediated cytosolic $\mathrm{Ca}^{2+}$ rise. These predictions were validated by experiments. i.e., ER $\mathrm{Ca}^{2+}$ content decreased and the cytosolic increase of $\mathrm{Ca}^{2+}$ was diminished in NCLX knockout/knockdown cells after the BCR activation. Comparable with the results obtained by use of astrocytes, SOCE activity in B lymphocytes was also diminished by silencing NCLX, probably further contributing to impairment of the cytosolic $\mathrm{Ca}^{2+}$ increase after BCR activation [47]. The reduction in $\mathrm{ER} \mathrm{Ca}^{2+}$ content was a result of impaired $\mathrm{Ca}^{2+}$ supply from mitochondria via NCLX, because $\mathrm{ER} \mathrm{Ca}^{2+}$ uptake via the ER $\mathrm{Ca}^{2+}$ pump SERCA was decelerated by NCLX reduction when mitochondrial respiration was intact (Fig. 5a) whereas it was comparable when mitochondrial respiration was disturbed [47]. Interesting findings were that NCLX reduction resulted in impaired co-localization of mitochondria with ER and augmented $\mathrm{ER} \mathrm{Ca}^{2+}$ leak. Although the cause remains unresolved, NCLX may be associated with the tethering proteins connecting ER and mitochondria [83, 84], and reduction of NCLX may weaken mitochondria-ER interactions. Alternatively, mitochondrial depolarization induced by NCLX knockout/knockdown might result in elimination of the impaired mitochondria by mitophagy [85]. Taken together, our results not only show that NCLX is involved in the crosstalk between mitochondria and the plasma membrane, as revealed by SOCE regulation, but also indicate that NCLX-mediated crosstalk between mitochondria and $\mathrm{ER} \mathrm{Ca}^{2+}$ dynamics is crucial for physiological functioning of B lymphocytes; i.e. a response to BCR activation. Very recently we found that silencing NCLX reduced the chemotaxis of B lymphocytes triggered by chemokine CXCL12, although the mechanism is still
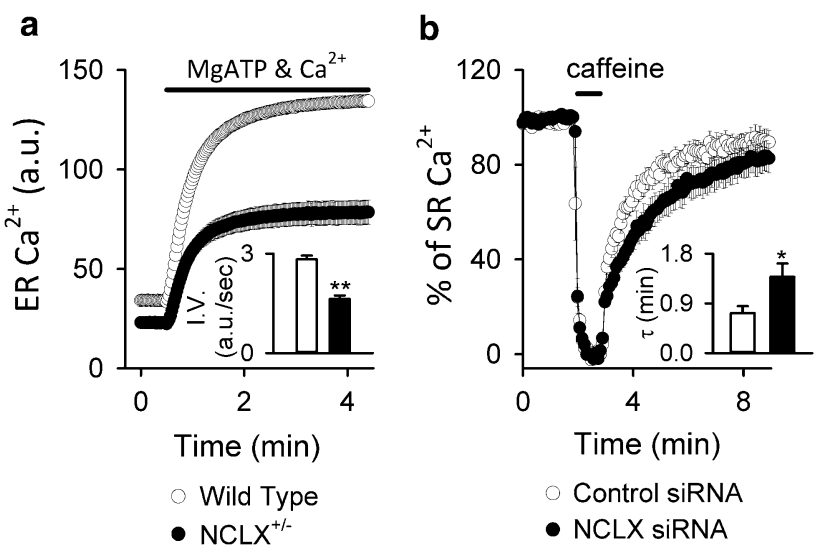

Fig. 5 Modulation of SERCA activity by NCLX reduction in (a) DT40 B lymphocytes and (b) HL-1 cardiomyocytes. a ER Ca ${ }^{2+}$ uptake by wild type and $\mathrm{NCLX}^{+/-}$DT40 cells. ER Ca ${ }^{2+}$ uptake were activated by applying $0.1 \mathrm{mM}$ MgATP and $100 \mathrm{nM} \mathrm{Ca}^{2+}$ in Mag Fluo-4-loaded and permeabilized cells under conditions in which mitochondrial respiration was intact. The bar graph depicts the initial velocity of the ER $\mathrm{Ca}^{2+}$ increase. Data are mean $\pm \mathrm{SEM}$ of independent recordings. Modified from Kim et al. [44]. b SR Ca ${ }^{2+}$ reuptake by HL-1 cardiomyocytes. Plasmid harbouring Cameleon D1ER, an indicator of SR $\mathrm{Ca}^{2+}$, was co-transfected with control (white) or NCLX siRNA (black) into HL-1 cardiomyoyctes. After emptying $\mathrm{Ca}^{2+}$ in SR with $10 \mathrm{mM}$ caffeine, recovery of SR $\mathrm{Ca}^{2+}$ was measured. The bar graph depicts the recovery time constant $\tau$, showing that $\mathrm{SR} \mathrm{Ca}^{2+}$ reuptake was slower in NCLX knockdown cells. ${ }^{* *} p<0.01,{ }^{*} p<0.05$. Modified from Takeuchi et al. [46]

unclear [86]. Although further analysis is needed, it is likely that NCLX is important in regulation of immune systems.

\section{NCLX in cardiomyocytes (Fig. 4d)}

The heart is one of the most studied organs for investigation of the characteristics of the mitochondrial $\mathrm{Na}^{+}-\mathrm{Ca}^{2+}$ exchanger, which serves as a major $\mathrm{Ca}^{2+}$ release system $[87,88]$. The roles of the mitochondrial $\mathrm{Na}^{+}-\mathrm{Ca}^{2+}$ exchanger in cardiac energetics have been widely investigated. For example, activation of the mitochondrial $\mathrm{Na}^{+}-$ $\mathrm{Ca}^{2+}$ exchanger by increasing cytosolic $\mathrm{Na}^{+}$causes a decrease of mitochondrial $\mathrm{Ca}^{2+}$, resulting in an imbalance in energy demand and supply or in an increase of ROS production $[89,90]$. In contrast, the contribution of the mitochondrial $\mathrm{Na}^{+}-\mathrm{Ca}^{2+}$ exchanger to cytosolic $\mathrm{Ca}^{2+}$ transients and to action potential generation has been regarded as negligible, because the contribution of mitochondrial $\mathrm{Ca}^{2+}$ uptake to $\mathrm{Ca}^{2+}$ release from cardiomyocytes is as low as 1-2\% [91]. However, we recently discovered that NCLX participates in modulation of action potential configuration and in regulation of the automaticity of HL-1, a spontaneously beating cardiac cell line originating from mouse atrial myocytes [48]. The expression patterns of ion channels and transporters in HL-1 cells 
are similar to those in adult atrial myocytes, except that HL-1 cells highly express the T-type $\mathrm{Ca}^{2+}$ channel $\left(I_{\mathrm{CaT}}\right)$ and the hyperpolarization-activated cation channel $\left(I_{\text {ha }}\right)$, which are known to be involved in the automaticity of cardiac pacemaker sinoatrial (SA) node cells [92-95]. NCLX reduction using siRNA reduced NCLX protein expression by $\sim 50 \%$, resulting in a $\sim 50 \%$ reduction of the rate of cytosolic $\mathrm{Na}^{+}$-dependent mitochondrial $\mathrm{Ca}^{2+}$ efflux, confirming that NCLX is responsible for mitochondrial $\mathrm{Na}^{+}-\mathrm{Ca}^{2+}$ exchange in HL-1 cells. Mitochondrial $\mathrm{Ca}^{2+}$ content, evaluated as the $\mathrm{Ca}^{2+}$ chelationresponsive fraction of the intensity of mitochondrial $\mathrm{Ca}^{2+}$ sensor pCase12-mito, was larger in NCLX knockdown cells. Although beat-to-beat change of mitochondrial $\mathrm{Ca}^{2+}$ was not observed in HL-1 cells, the result indicated that NCLX contributes to the steady state mitochondrial $\mathrm{Ca}^{2+}$ content in intact HL-1 cells. Cellular energetics seemed to be unaffected by NCLX knockdown, because there were no differences in cellular ATP content, mitochondrial membrane potential, or mitochondrial ROS between control cells and NCLX knockdown cells. This may be because protein expression of NCLX knockdown using siRNA was reduced by $50 \%$ only.

An interesting finding was that NCLX knockdown caused marked prolongation of the cycle length of spontaneous action potentials and $\mathrm{Ca}^{2+}$ transients [48]. Kinetic analysis of electrophysiological data and $\mathrm{Ca}^{2+}$ transients obtained by line scanning cells loaded with cytosolic $\mathrm{Ca}^{2+}$ indicator Fluo-4 revealed that NCLX knockdown slowed the upstrokes of both action potentials and cytosolic $\mathrm{Ca}^{2+}$ transients. SR $\mathrm{Ca}^{2+}$ dynamics, which is known to contribute to the upstroke of cytosolic $\mathrm{Ca}^{2+}$ transients, was evaluated by use of ER/SR $\mathrm{Ca}^{2+}$ FRET protein cameleon D1ER [96]. As a result, SR $\mathrm{Ca}^{2+}$ content of NCLX knockdown cells was smaller and SR $\mathrm{Ca}^{2+}$ reuptake rate was slower (Fig. 5b), suggesting that the NCLX reductionmediated prolongation of cycle length is related to compromised SR $\mathrm{Ca}^{2+}$ dynamics. The mechanisms underlying the NCLX reduction-mediated prolongation of cycle length was further studied with a newly constructed mathematical model of HL-1 cells [48]. The HL-1 cell model well reproduces the spontaneous generation of action potentials and $\mathrm{Ca}^{2+}$ transients, and the prolongation of the cycle length induced by knocking down NCLX. The model analysis indicated that automaticity of HL-1 cells is determined by spontaneous $\mathrm{Ca}^{2+}$ leak from the SR. Simulation of NCLX reduction showed that $\mathrm{Ca}^{2+}$ supply from the mitochondria to the SR decreased to slow down the rate of spontaneous $\mathrm{Ca}^{2+}$ leak from the SR. The timing of $\mathrm{Ca}^{2+}$-induced $\mathrm{Ca}^{2+}$ release (CICR), activation of the inward current of the plasma membrane $\mathrm{NCX}\left(I_{\mathrm{NCX}}\right)$, and thus the timing of activation of voltage-dependent $\mathrm{Na}^{+}$ current $\left(I_{\mathrm{Na}}\right)$ and voltage-dependent $\mathrm{T}$ and $\mathrm{L}$ type $\mathrm{Ca}^{2+}$ channels $\left(I_{\mathrm{CaT}}\right.$ and $\left.I_{\mathrm{CaL}}\right)$ was thus delayed, resulting in prolongation of the cycle length. Taken together, our combined experiments and simulations indicated that NCLX regulates the rhythmicity of HL-1 cells via crosstalk between mitochondria and SR $\mathrm{Ca}^{2+}$ dynamics. Considering that NCLX reduction resulted in modification of plasma membrane NCX activity, NCLX may also be indirectly involved in mitochondria-plasma membrane $\mathrm{Ca}^{2+}$ crosstalk in HL-1 cells. Interestingly, Opuni and Reeves reported the functional coupling of mitochondrial function, possibly mitochondrial $\mathrm{Na}^{+}-\mathrm{Ca}^{2+}$ exchange activity, and plasma membrane NCX activity in Chinese hamster ovary cells stably transfected with bovine cardiac NCX [97]. Further analysis is necessary to elucidate the interaction of mitochondrial NCLX and plasma membrane NCX. Because HL-1 cells are derived from atrial myocytes, which have no automaticity under physiological conditions, NCLX may be involved in the abnormal automaticity of atria, for example atrial flutter or atrial ectopic tachycardia. It may also be possible that occurrence of arrhythmia in patients with mitochondrial disease [98, 99] is caused by abnormal NCLX function. Further analysis is required to clarify the involvement of NCLX in these arrhythmias.

Whether NCLX participates in the automaticity of normal pacemaker cells, sinoatrial (SA) node cells, is a big issue. Recently, Yaniv et al. [100] reported that mitochondrial $\mathrm{Na}^{+}-\mathrm{Ca}^{2+}$ exchange inhibitor CGP-37157 slowed the generation of automaticity of rabbit SA node cells, suggesting that mitochondrial $\mathrm{Na}^{+}-\mathrm{Ca}^{2+}$ exchange is involved in generation of the automaticity of SA node cells. However, because CGP-37157 also blocks $I_{\mathrm{CaL}}$, which is related to generation of the automaticity of SA node cells, a nonspecific effect of CGP-37157 on $I_{\mathrm{CaL}}$ cannot be ignored. In addition, the automaticity of the SA node cells they used significantly depends on spontaneous and local subsarcolemmal $\mathrm{Ca}^{2+}$ releases from SR, the so called " $\mathrm{Ca}^{2+}$ clock" mechanism [101]. However, this automaticity mechanism has been controversial. It has been accepted for a long time that $I_{\text {ha }}$ and a variety of other inward membrane currents determine the automaticity [102-104]. This mechanism is called the "membrane clock". Whether NCLX contributes to the automaticity of all types of SA node cells, including the cells driven by "membrane clock", must be studied.

We examined the contribution of NCLX using mathematical models of SA node cells [105]. In the original SA node model developed by Yaniv et al. [100], complete reduction of mitochondrial $\mathrm{Na}^{+}-\mathrm{Ca}^{2+}$ exchange resulted in prolongation of cycle length by $2.7 \%$ only. The larger effect reported by Yaniv et al. [100] is probably because of their simultaneous reduction of the amplitude factor of SERCA. To further test the contribution of NCLX to 
generation of the automaticity of SA node cell models, we incorporated our model of mitochondrial $\mathrm{Ca}^{2+}$ dynamics into two representative SA node cell models: a membrane clock model by Himeno et al. $[102,103]$ and a $\mathrm{Ca}^{2+}$ clock model by Maltsev and Lakatta [101]. In both models, NCLX reduction reduced the SR $\mathrm{Ca}^{2+}$ content, supporting the idea of $\mathrm{Ca}^{2+}$ communication between mitochondria and the SR in SA node cells. However, the effect on the automaticity was different between the models. The cycle length was prolonged in the Maltsev and Lakatta model whereas it was shortened in the Himeno model [105]. Furthermore, model analysis revealed that cytosolic $\mathrm{Na}^{+}$ and $\mathrm{Na}^{+}$-permeable inward current (sustained inward current $I_{\mathrm{st}}$ ) [106] are crucial factors distinguishing the effect of NCLX on pace-making in the two models. In the Himeno model, NCLX reduction reduced cytosolic $\mathrm{Ca}^{2+}$, which decreased the inward $I_{\mathrm{NCX}}$ thus reducing the cytosolic $\mathrm{Na}^{+}$ concentration. This increased the amplitude of the inward $I_{\mathrm{st}}$ and overcame the decrease of inward $I_{\mathrm{NCX}}$, accelerating the firing rate. In contrast, the amplitude of $I_{\mathrm{st}}$ is set smaller in the Maltsev and Lakatta model so that NCLX reduction only reduces inward $I_{\mathrm{NCX}}$ and slows diastolic depolarization, decelerating the firing rate [105]. Accordingly, it is likely that the $\mathrm{Ca}^{2+}$ communication between mitochondria and the SR via NCLX functions also in SA node cells. However, it is necessary to investigate quantitatively how much the " $\mathrm{Ca}^{2+}$ clock" mechanism, cytoplasmic $\mathrm{Na}^{+}$, and $I_{\text {st }}$ contribute to SA node automaticity.

Mitochondrial $\mathrm{H}^{+}-\mathrm{Ca}^{2+}$ exchanger

$\mathrm{H}^{+}-\mathrm{Ca}^{2+}$ exchange has a dominant effect on release of $\mathrm{Ca}^{2+}$ from mitochondria in tissues in which mitochondrial $\mathrm{Na}^{+}-\mathrm{Ca}^{2+}$ exchange activity is low, for example the liver, kidney, lung, and smooth muscle [61]. The $\mathrm{H}^{+}-\mathrm{Ca}^{2+}$ exchanger also occurs in the heart, though the activity is weak $[61,107]$.

The stoichiometry of the $\mathrm{H}^{+}-\mathrm{Ca}^{2+}$ exchanger is regarded as $2 \mathrm{H}^{+}$for $1 \mathrm{Ca}^{2+}$, being electroneutral. However, because the rate of efflux via the $\mathrm{H}^{+}-\mathrm{Ca}^{2+}$ exchanger decreases with increasing $\mathrm{pH}$ gradient in rat isolated liver mitochondria, it is suggested that the mechanism is not a passive $\mathrm{Ca}^{2+}$ for $2 \mathrm{H}^{+}$exchanger, but an active $\mathrm{Ca}^{2+}$ for $2 \mathrm{H}^{+}$exchanger [108].

The molecular identity of the mitochondrial $\mathrm{H}^{+}-\mathrm{Ca}^{2+}$ exchanger is still controversial. The candidate is the Letm 1 (leucine-zipper-EF hand-containing transmembrane region). Jiang et al. [11] conducted high-throughput RNA interference screening of Drosophila genes and identified a gene affecting mitochondrial $\mathrm{Ca}^{2+}$ and $\mathrm{H}^{+}$, the human homolog of which is Letm1. By using digitonin-permeabilized S2 or 293 cells expressing mitochondrial $\mathrm{Ca}^{2+}$ sensor protein pericam, or by using purified Letm1 reconstituted in liposomes, they found that Letm 1 mediates $\mathrm{H}^{+}-\mathrm{Ca}^{2+}$ exchange. However, because a drastic reduction of mitochondrial $\mathrm{Ca}^{2+}$ uptake was observed when Letm1 protein expression was suppressed, and because $\mathrm{H}^{+}-\mathrm{Ca}^{2+}$ exchange via Letm1 was sensitive to an inhibitor of mitochondrial $\mathrm{Ca}^{2+}$ influx, ruthenium red, Letm1 is regarded as mediating $\mathrm{Ca}^{2+}$ influx into mitochondria, at least at low cytosolic $\mathrm{Ca}^{2+}$ level. This idea was confirmed by subsequent work by Jiang et al. [109] in which Letm1 knockdown in 293 cells resulted in dramatically reduced mitochondrial $\mathrm{Ca}^{2+}$ content. In the same work they produced Letm1 knockout mice and found that Letm1 homozygous knockout mice were embryonic lethal and so were half of the heterozygous knockout mice. The surviving mice had altered glucose metabolism, impaired control of brain ATP levels, and increased seizure activity, suggesting involvement of Letm1 in the pathology of Wolf-Hirschhorn syndrome, in which Letm1 is known to be one of the genes deleted [110]. Nowikovsky et al. [111] analysed theoretically the direction of $\mathrm{Ca}^{2+}$ flux through the mitochondrial membrane in energized mitochondria with different $\mathrm{H}^{+}: \mathrm{Ca}^{2+}$ stoichiometry. They proposed that $\mathrm{Ca}^{2+}$ enters mitochondria with $1 \mathrm{H}^{+}: 1 \mathrm{Ca}^{2+}$ whereas $\mathrm{Ca}^{2+}$ leaves mitochondria with $2 \mathrm{H}^{+}: 1 \mathrm{Ca}^{2+}$ or $3 \mathrm{H}^{+}: 1 \mathrm{Ca}^{2+}$ stoichiometry under physiological respiration conditions. Tsai et al. [112] reported that Letm1 mediates the electroneutral $2 \mathrm{H}^{+}: 1 \mathrm{Ca}^{2+}$ antiport and is insensitive to ruthenium red, by using Letm1 reconstituted proteoliposome. These results combined with the theoretical analysis by Nowikovsky et al. [111] strongly suggest that Letm1 is the long-awaited molecular identity of the mitochondrial $\mathrm{H}^{+}-\mathrm{Ca}^{2+}$ exchanger. There is, currently, no reasonable explanation of the discrepancy of the sensitivity of Letm1 to ruthenium red. We independently found that a substantial part of the $\mathrm{Ca}^{2+}$ efflux from mitochondria was independent of cytosolic $\mathrm{Na}^{+}$when mitochondria were loaded with a lower concentration of $\mathrm{Ca}^{2+}$ than when examining $\mathrm{Na}^{+}-\mathrm{Ca}^{2+}$ exchange activity using A20 B lymphocytes [46]. This fraction, which probably represents the $\mathrm{H}^{+}-\mathrm{Ca}^{2+}$ exchange system, was sensitive to ruthenium red. Further analysis is necessary to determine whether Letm 1 is, indeed, the $\mathrm{H}^{+}-\mathrm{Ca}^{2+}$ exchanger mediating $\mathrm{Ca}^{2+}$ extrusion from mitochondria.

\section{Summary}

$\mathrm{Ca}^{2+}$, not only inside mitochondria but also released from mitochondria, is crucially important in regulating a variety of cellular physiological functions. Identification of the molecules responsible for the pathways of $\mathrm{Ca}^{2+}$ release enables us to isolate the contributions of these molecules. For example, NCLX has been shown to participate in 
insulin secretion in pancreatic $\beta$-cells, glutamate release in astrocytes, $\mathrm{Ca}^{2+}$ responsiveness to BCR stimulation in $\mathrm{B}$ lymphocytes, and generation of the spontaneous rhythmicity of cadiomyocytes, via $\mathrm{Ca}^{2+}$ crosstalk between mitochondria and the plasma membrane and/or between mitochondria and the ER/SR (Fig. 4). However, many issues remain unanswered. One is the question of whether mitochondrial $\mathrm{Ca}^{2+}$ release proteins are indeed located in the tethering spots between mitochondria and the ER/SR or between mitochondria and the plasma membrane. Another is the contribution of the mitochondrial $\mathrm{Ca}^{2+}$ release system to mitochondrial energetics. Distinct phenotypes of NCLX knockdown cells related to mitochondrial energetics in cardiomyocytes and in pancreatic $\beta$-cells have not been observed, while Letm1 knockout mice had impaired mitochondrial energetics. Complete knockout of NCLX in mice or cells will clarify the matter.

Acknowledgments This work was supported by JSPS Kakenhi grant numbers 25136707, 23689011, and 23390042 (A.T. and S.M.).

Conflict of interest The authors declare that they have no conflict of interest.

Open Access This article is distributed under the terms of the Creative Commons Attribution License which permits any use, distribution, and reproduction in any medium, provided the original author(s) and the source are credited.

\section{References}

1. Bernardi P (1999) Mitochondrial transport of cations: channels, exchangers, and permeability transition. Physiol Rev 79:1127-1155

2. Murgia M, Giorgi C, Pinton P, Rizzuto R (2009) Controlling metabolism and cell death: at the heart of mitochondrial calcium signalling. J Mol Cell Cardiol 46:781-788

3. Celsi F, Pizzo P, Brini M, Leo S, Fotino C, Pinton P, Rizzuto R (2009) Mitochondria, calcium and cell death: a deadly triad in neurodegeneration. Biochim Biophys Acta 1787:335-344

4. De Stefani D, Raffaello A, Teardo E, Szabò I, Rizzuto R (2011) A forty-kilodalton protein of the inner membrane is the mitochondrial calcium uniporter. Nature 476:336-340

5. Baughman JM, Perocchi F, Girgis HS, Plovanich M, BelcherTimme CA, Sancak Y, Bao XR, Strittmatter L, Goldberger O, Bogorad RL, Koteliansky V, Mootha VK (2011) Integrative genomics identifies MCU as an essential component of the mitochondrial calcium uniporter. Nature 476:341-345

6. Niescier RF, Chang KT, Min KT (2013) Miro, MCU, and calcium: bridging our understanding of mitochondrial movement in axons. Front Cell Neurosci 7:148

7. Patron M, Raffaello A, Granatiero V, Tosatto A, Merli G, De Stefani D, Wright L, Pallafacchina G, Terrin A, Mammucari C, Rizzuto R (2013) The mitochondrial calcium uniporter (MCU): molecular identity and physiological roles. J Biol Chem 288:10750-10758

8. Marchi S, Pinton P (2014) The mitochondrial calcium uniporter complex: molecular components, structure and physiopathological implications. J Physiol 592:829-839
9. Carafoli E, Tiozzo R, Lugli G, Crovetti F, Kratzing C (1974) The release of calcium from heart mitochondria by sodium. J Mol Cell Cardiol 6:361-371

10. Palty R, Silverman WF, Hershfinkel M, Caporale T, Sensi SL, Parnis J, Nolte C, Fishman D, Shoshan-Barmatz V, Herrmann S, Khananshvili D, Sekler I (2010) NCLX is an essential component of mitochondrial $\mathrm{Na}^{+} / \mathrm{Ca}^{2+}$ exchange. Proc Natl Acad Sci U S A 107:436-441

11. Jiang D, Zhao L, Clapham DE (2009) Genome-wide RNAi screen identifies Letm 1 as a mitochondrial $\mathrm{Ca}^{2+} / \mathrm{H}^{+}$antiporter. Science 326:144-147

12. Rowland AA, Voeltz GK (2012) Endoplasmic reticulum-mitochondria contacts: function of the junction. Nat Rev Mol Cell Biol 13:607-625

13. van Vliet AR, Verfaillie T, Agostinis P (2014) New functions of mitochondria associated membranes in cellular signaling. Biochim Biophys Acta (in press). doi:10.1016/j.bbamcr.2014.03. 009

14. McCormack JG, Halestrap AP, Denton RM (1990) Role of calcium ions in regulation of mammalian intramitochondrial metabolism. Physiol Rev 70:391-425

15. Jo H, Noma A, Matsuoka S (2006) Calcium-mediated coupling between mitochondrial substrate dehydrogenation and cardiac workload in single guinea-pig ventricular myocytes. J Mol Cell Cardiol 40:394-404

16. Satrústegui J, Pardo B, Del Arco A (2007) Mitochondrial transporters as novel targets for intracellular calcium signalin. Physiol Rev 87:29-67

17. Chacon E, Acosta D (1991) Mitochondrial regulation of superoxide by $\mathrm{Ca}^{2+}$ : an alternate mechanism for the cardiotoxicity of doxorubicin. Toxicol Appl Pharmacol 107:117-128

18. Gandhi S, Wood-Kaczmar A, Yao Z, Plun-Favreau H, Deas E, Klupsch K, Downward J, Latchman DS, Tabrizi SJ, Wood NW, Duchen MR, Abramov AY (2009) PINK1-associated Parkinson's disease is caused by neuronal vulnerability to calciuminduced cell death. Mol Cell 33:627-638

19. Harris DA (1993) Regulation of the mitochondrial ATP synthase in rat heart. Biochem Soc Trans 21:778-781

20. Scholz TD, Balaban RS (1994) Mitochondrial F1-ATPase activity of canine myocardium: effects of hypoxia and stimulation. Am J Physiol 266:H2396-H2403

21. Crompton M (1999) The mitochondrial permeability transition pore and its role in cell death. Biochem J 341:233-249

22. Bernardi P, Krauskopf A, Basso E, Petronilli V, Blachly-Dyson E, Di Lisa F, Forte MA (2006) The mitochondrial permeability transition from in vitro artifact to disease target. FEBS J 273:2077-2099

23. Rizzuto R, De Stefani D, Raffaello A, Mammucari C (2012) Mitochondria as sensors and regulators of calcium signalling. Nat Rev Mol Cell Biol 13:566-578

24. Wang X (2001) The expanding role of mitochondria in apoptosis. Genes Dev 15:2922-2933

25. Hajnóczky G, Davies E, Madesh M (2003) Calcium signaling and apoptosis. Biochem Biophys Res Commun 304:445-454

26. Lemasters JJ, Theruvath TP, Zhong Z, Nieminen AL (2009) Mitochondrial calcium and the permeability transition in cell death. Biochim Biophys Acta 1787:1395-1401

27. Dedkova EN, Blatter LA (2009) Characteristics and function of cardiac mitochondrial nitric oxide synthase. J Physiol 587:851-872

28. Tidow H, Nissen P (2013) Structural diversity of calmodulin binding to its target sites. FEBS J 280:5551-5565

29. Gilabert JA (2012) Cytoplasmic calcium buffering. Adv Exp Med Biol 740:483-498 
30. Lawrie AM, Rizzuto R, Pozzan T, Simpson AW (1996) A role for calcium influx in the regulation of mitochondrial calcium in endothelial cells. J Biol Chem 271:10753-10759

31. Babcock DF, Herrington J, Goodwin PC, Park YB, Hille B (1997) Mitochondrial participation in the intracellular $\mathrm{Ca}^{2+}$ network. J Cell Biol 136:833-844

32. Park MK, Ashby MC, Erdemli G, Petersen OH, Tepikin AV (2001) Perinuclear, perigranular and sub-plasmalemmal mitochondria have distinct functions in the regulation of cellular calcium transport. EMBO J 20:1863-1874

33. Giacomello M, Drago I, Bortolozzi M, Scorzeto M, Gianelle A, Pizzo P, Pozzan $\mathrm{T}$ (2010) $\mathrm{Ca}^{2+}$ hot spots on the mitochondrial surface are generated by $\mathrm{Ca}^{2+}$ mobilization from stores, but not by activation of store-operated $\mathrm{Ca}^{2+}$ channels. Mol Cell 38:280-290

34. Hoth M, Fanger CM, Lewis RS (1997) Mitochondrial regulation of store-operated calcium signaling in $\mathrm{T}$ lymphocytes. $\mathrm{J}$ Cell Biol 137:633-648

35. Glitsch MD, Bakowski D, Parekh AB (2002) Store-operated $\mathrm{Ca}^{2+}$ entry depends on mitochondrial $\mathrm{Ca}^{2+}$ uptake. EMBO J 21:6744-6754

36. Csordás G, Renken C, Varnai P, Walter L, Weaver D, Buttle KF, Balla T, Mannella CA, Hajnóczky G (2006) Structural and functional features and significance of the physical linkage between ER and mitochondria. J Cell Biol 174:915-921

37. Friedman JR, Lackner LL, West M, DiBenedetto JR, Nunnari J, Voeltz GK (2011) ER tubules mark sites of mitochondrial division. Science 334:358-362

38. Sharma VK, Ramesh V, Franzini-Armstrong C, Sheu SS (2000) Transport of $\mathrm{Ca}^{2+}$ from sarcoplasmic reticulum to mitochondria in rat ventricular myocytes. J Bioenerg Biomembr 32:97-104

39. Csordás G, Várnai P, Golenár T, Roy S, Purkins G, Schneider TG, Balla T, Hajnóczky G (2010) Imaging interorganelle contacts and local calcium dynamics at the ER-mitochondrial interface. Mol Cell 39:121-132

40. Rizzuto R (1998) Close contacts with the endoplasmic reticulum as determinants of mitochondrial $\mathrm{Ca}^{2+}$ responses. Science 280:1763-1766

41. Mendes CC, Gomes DA, Thompson M, Souto NC, Goes TS, Goes AM, Rodrigues MA, Gomez MV, Nathanson MH, Leite MF (2005) The type III inositol 1,4,5-trisphosphate receptor preferentially transmits apoptotic $\mathrm{Ca}^{2+}$ signals into mitochondria. J Biol Chem 280:40892-40900

42. Szabadkai G, Bianchi K, Várnai P, De Stefani D, Wieckowski MR, Cavagna D, Nagy AI, Balla T, Rizzuto R (2006) Chaperone-mediated coupling of endoplasmic reticulum and mitochondrial $\mathrm{Ca}^{2+}$ channels. J Cell Biol 175:901-911

43. Arnaudeau S, Kelley WL, Walsh JV Jr, Demaurex N (2001) Mitochondria recycle $\mathrm{Ca}^{2+}$ to the endoplasmic reticulum and prevent the depletion of neighboring endoplasmic reticulum regions. J Biol Chem 276:29430-29439

44. Malli R, Frieden M, Trenker M, Graier WF (2005) The role of mitochondria for $\mathrm{Ca}^{2+}$ refilling of the endoplasmic reticulum. J Biol Chem 280:12114-12122

45. Poburko D, Liao CH, van Breemen C, Demaurex N (2009) Mitochondrial regulation of sarcoplasmic reticulum $\mathrm{Ca}^{2+}$ content in vascular smooth muscle cells. Circ Res 104:104-112

46. Kim B, Takeuchi A, Koga O, Hikida M, Matsuoka S (2012) Pivotal role of mitochondrial $\mathrm{Na}^{+}-\mathrm{Ca}^{2+}$ exchange in antigen receptor mediated $\mathrm{Ca}^{2+}$ signalling in DT40 and A20 B lymphocytes. J Physiol 590:459-474

47. Kim B, Takeuchi A, Koga O, Hikida M, Matsuoka S (2013) Mitochondria $\mathrm{Na}^{+}-\mathrm{Ca}^{2+}$ exchange in cardiomyocytes and lymphocytes. Adv Exp Med Biol 961:193-201

48. Takeuchi A, Kim B, Matsuoka S (2013) The mitochondrial $\mathrm{Na}^{+}-\mathrm{Ca}^{2+}$ exchanger, NCLX, regulates automaticity of HL-1 cardiomyocytes. Sci Rep 3:2766
49. Deluca HF, Engstrom GW (1961) Calcium uptake by rat kidney mitochondria. Proc Natl Acad Sci U S A 47:1744-1750

50. Vasington FD, Murphy JV (1962) $\mathrm{Ca}^{++}$uptake by rat kidney mitochondria and its dependence on respiration and phosphorylation. J Biol Chem 237:2670-2677

51. Fiskum G, Lehninger AL (1979) Regulated release of $\mathrm{Ca}^{2+}$ from respiring mitochondria by $\mathrm{Ca}^{2+} / 2 \mathrm{H}^{+}$antiport. $\mathrm{J}$ Biol Chem 254:6236-6239

52. Gunter TE, Yule DI, Gunter KK, Eliseev RA, Salter JD (2004) Calcium and mitochondria. FEBS Lett 567:96-102

53. Carafoli E (2010) The fateful encounter of mitochondria with calcium: how did it happen? Biochim Biophys Acta 1797:595-606

54. Malli R, Graier WF (2010) Mitochondrial $\mathrm{Ca}^{2+}$ channels: great unknowns with important functions. FEBS Lett 584:1942-1947

55. Kirichok Y, Krapivinsky G, Clapham DE (2004) The mitochondrial calcium uniporter is a highly selective ion channel. Nature 427:360-364

56. Perocchi F, Gohil VM, Girgis HS, Bao XR, McCombs JE, Palmer AE, Mootha VK (2010) MICU1 encodes a mitochondrial $\mathrm{EF}$ hand protein required for $\mathrm{Ca}^{2+}$ uptake. Nature 467:291-296

57. Huang G, Vercesi AE, Docampo R (2013) Essential regulation of cell bioenergetics in Trypanosoma brucei by the mitochondrial calcium uniporter. Nat Commun 4:2865

58. Pan X, Liu J, Nguyen T, Liu C, Sun J, Teng Y, Fergusson MM, Rovira II, Allen M, Springer DA, Aponte AM, Gucek M, Balaban RS, Murphy E, Finkel T (2013) The physiological role of mitochondrial calcium revealed by mice lacking the mitochondrial calcium uniporter. Nat Cell Biol 15:1464-1472

59. Crompton M, Moser R, Lüdi H, Carafoli E (1978) The interrelations between the transport of sodium and calcium in mitochondria of various mammalian tissues. Eur $\mathrm{J}$ Biochem 82:25-31

60. Haworth RA, Hunter DR, Berkoff HA (1980) $\mathrm{Na}^{+}$releases $\mathrm{Ca}^{2+}$ from liver, kidney and lung mitochondria. FEBS Lett 110:210-218

61. Gunter TE, Pfeiffer DR (1990) Mechanisms by which mitochondria transport calcium. Am J Physiol 258:C755-C786

62. Affolter H, Carafoli E (1980) The $\mathrm{Ca}^{2+}-\mathrm{Na}^{+}$antiporter of heart mitochondria operates electroneutrally. Biochem Biophys Res Commun 95:193-196

63. Wingrove DE, Gunter TE (1986) Kinetics of mitochondrial calcium transport. II. A kinetic description of the sodiumdependent calcium efflux mechanism of liver mitochondria and inhibition by ruthenium red and by tetraphenylphosphonium. J Biol Chem 261:15166-15171

64. Kim B, Matsuoka S (2008) Cytoplasmic $\mathrm{Na}^{+}$-dependent modulation of mitochondrial $\mathrm{Ca}^{2+}$ via electrogenic mitochondrial $\mathrm{Na}^{+}-\mathrm{Ca}^{2+}$ exchange. J Physiol 586:1683-1697

65. Da Cruz S, De Marchi U, Frieden M, Parone PA, Martinou JC, Demaurex N (2010) SLP-2 negatively modulates mitochondrial sodium-calcium exchange. Cell Calcium 47:11-18

66. Cai X, Lytton J (2004) Molecular cloning of a sixth member of the $\mathrm{K}^{+}$-dependent $\mathrm{Na}^{+} / \mathrm{Ca}^{2+}$ exchanger gene family, NCKX6. J Biol Chem 279:5867-5876

67. Palty R, Ohana E, Hershfinkel M, Volokita M, Elgazar V, Beharier O, Silverman WF, Argaman M, Sekler I (2004) Lithium-calcium exchange is mediated by a distinct potassiumindependent sodium-calcium exchanger. $\mathrm{J}$ Biol Chem 279:25234-25240

68. Nagai T, Sawano A, Park ES, Miyawaki A (2001) Circularly permuted green fluorescent proteins engineered to sense $\mathrm{Ca}^{2+}$. Proc Natl Acad Sci U S A 98:3197-3202

69. Ashcroft FM (2007) ATP-sensitive $\mathrm{K}^{+}$channels and disease: from molecule to malady. Am J Physiol Endocrinol Metab 293:E880-E889 
70. Ashcroft SJ, Weerasinghe LC, Randle PJ (1973) Interrelationship of islet metabolism, adenosine triphosphate content and insulin release. Biochem J 132:223-231

71. Kennedy HJ (1999) Glucose generates sub-plasma membrane ATP microdomains in single islet $\beta$-cells. Potential role for strategically located mitochondria. J Biol Chem 274:13281-13291

72. Tarasov AI, Semplici F, Ravier MA, Bellomo EA, Pullen TJ, Gilon P, Sekler I, Rizzuto R, Rutter GA (2012) The mitochondrial $\mathrm{Ca}^{2+}$ uniporter MCU is essential for glucose-induced ATP increases in pancreatic $\beta$-cells. PLoS ONE 7:e39722

73. Nita II, Hershfinkel M, Fishman D, Ozeri E, Rutter GA, Sensi SL, Khananshvili D, Lewis EC, Sekler I (2012) The mitochondrial $\mathrm{Na}^{+} / \mathrm{Ca}^{2+}$ exchanger upregulates glucose dependent $\mathrm{Ca}^{2+}$ signalling linked to insulin secretion. PLoS ONE 7:e46649

74. Molina AJ, Wikstrom JD, Stiles L, Las G, Mohamed H, Elorza A, Walzer G, Twig G, Katz S, Corkey BE, Shirihai OS (2009) Mitochondrial networking protects $\beta$-cells from nutrientinduced apoptosis. Diabetes 58:2303-2315

75. Proverbio MC, Mangano E, Gessi A, Bordoni R, Spinelli R, Asselta R, Valin PS, Di Candia S, Zamproni I, Diceglie C, Mora S, Caruso-Nicoletti M, Salvatoni A, De Bellis G, Battaglia C (2013) Whole genome SNP genotyping and exome sequencing reveal novel genetic variants and putative causative genes in congenital hyperinsulinism. PLoS ONE 8:e68740

76. Agulhon C, Petravicz J, McMullen AB, Sweger EJ, Minton SK, Taves SR, Casper KB, Fiacco TA, McCarthy KD (2008) What is the role of astrocyte calcium in neurophysiology? Neuron 59:932-946

77. Navarrete M, Araque A (2008) Endocannabinoids mediate neuron-astrocyte communication. Neuron 57:883-893

78. Serrano A, Haddjeri N, Lacaille JC, Robitaille R (2006) GABAergic network activation of glial cells underlies hippocampal heterosynaptic depression. J Neurosci 26:5370-5382

79. Parnis J, Montana V, Delgado-Martinez I, Matyash V, Parpura V, Kettenmann H, Sekler I, Nolte C (2013) Mitochondrial exchanger NCLX plays a major role in the intracellular $\mathrm{Ca}^{2+}$ signaling, gliotransmission, and proliferation of astrocytes. J Neurosci 33:7206-7219

80. Scharenberg AM, Humphries LA, Rawlings DJ (2007) Calcium signalling and cell-fate choice in B cells. Nat Rev Immunol 7:778-789

81. Feske S (2007) Calcium signalling in lymphocyte activation and disease. Nat Rev Immunol 7:690-702

82. Vig M, Kinet JP (2009) Calcium signaling in immune cells. Nat Immunol 10:21-27

83. Pinton P, Giorgi C, Siviero R, Zecchini E, Rizzuto R (2008) Calcium and apoptosis: ER-mitochondria $\mathrm{Ca}^{2+}$ transfer in the control of apoptosis. Oncogene 27:6407-6418

84. Csordás G, Hajnóczky G (2009) SR/ER-mitochondrial local communication: calcium and ROS. Biochim Biophys Acta 1787:1352-1362

85. Youle RJ, Narendra DP (2011) Mechanisms of mitophagy. Nat Rev Mol Cell Biol 12:9-14

86. Kim B, Takeuchi A, Matsuoka S (2013) Mitochondrial NCX controls directional migration of B lymphocyte. J Physiol Sci 63:S136

87. Crompton M, Künzi M, Carafoli E (1977) The calcium-induced and sodium-induced effluxes of calcium from heart mitochondria. Evidence for a sodium-calcium carrier. Eur J Biochem 79:549-558

88. Wei AC, Liu T, Cortassa S, Winslow RL, O'Rourke B (2011) Mitochondrial $\mathrm{Ca}^{2+}$ influx and efflux rates in guinea pig cardiac mitochondria: low and high affinity effects of cyclosporine A. Biochim Biophys Acta 1813:1373-1381

89. Liu T, O'Rourke B (2008) Enhancing mitochondrial $\mathrm{Ca}^{2+}$ uptake in myocytes from failing hearts restores energy supply and demand matching. Circ Res 103:279-288
90. Kohlhaas M, Liu T, Knopp A, Zeller T, Ong MF, Bohm M, O'Rourke B, Maack C (2010) Elevated cytosolic $\mathrm{Na}^{+}$increases mitochondrial formation of reactive oxygen species in failing cardiac myocytes. Circulation 121:1606-1613

91. Bassani RA, Bassani JW, Bers DM (1994) Relaxation in ferret ventricular myocytes: unusual interplay among calcium transport systems. J Physiol 476:295-308

92. Claycomb WC, Lanson NAJ, Stallworth BS, Egeland DB, Delcarpio JB, Bahinski A, Izzo NJJ (1998) HL-1 cells: a cardiac muscle cell line that contracts and retains phenotypic characteristics of the adult cardiomyocyte. Proc Natl Acad Sci U S A 95:2979-2984

93. White SM, Constantin PE, Claycomb WC (2004) Cardiac physiology at the cellular level: use of cultured HL-1 cardiomyocytes for studies of cardiac muscle cell structure and function. Am J Physiol Heart Circ Physiol 286:H823-H829

94. Yang Z, Murray KT (2011) Ionic mechanisms of pacemaker activity in spontaneously contracting atrial HL-1 cells. J Cardiovasc Pharmacol 57:28-36

95. Adachi T, Shibata S, Okamoto Y, Sato S, Fujisawa S, Ohba T, Ono K (2013) The mechanism of increased postnatal heart rate and sinoatrial node pacemaker activity in mice. J Physiol Sci 63:133-146

96. Palmer AE, Jin C, Reed JC, Tsien RY (2004) Bcl-2-mediated alterations in endoplasmic reticulum $\mathrm{Ca}^{2+}$ analyzed with an improved genetically encoded fluorescent sensor. Proc Natl Acad Sci U S A 101:17404-17409

97. Opuni K, Reeves JP (2000) Feedback inhibition of sodium/ calcium exchange by mitochondrial calcium accumulation. J Biol Chem 275:21549-21554

98. Khatami M, Houshmand M, Sadeghizadeh M, Eftekharzadeh M, Heidari MM, Saber S, Banihashemi K, Scheiber-Mojdehkar B (2010) Accumulation of mitochondrial genome variations in Persian LQTS patients: a possible risk factor? Cardiovasc Pathol 19:e21-e27

99. Koopman WJ, Willems PH, Smeitink JA (2012) Monogenic mitochondrial disorders. N Engl J Med 366:1132-1141

100. Yaniv Y, Spurgeon HA, Lyashkov AE, Yang D, Ziman BD, Maltsev VA, Lakatta EG (2012) Crosstalk between mitochondrial and sarcoplasmic reticulum $\mathrm{Ca}^{2+}$ cycling modulates cardiac pacemaker cell automaticity. PLoS ONE 7:e37582

101. Maltsev VA, Lakatta EG (2009) Synergism of coupled subsarcolemmal $\mathrm{Ca}^{2+}$ clocks and sarcolemmal voltage clocks confers robust and flexible pacemaker function in a novel pacemaker cell model. Am J Physiol Heart Circ Physiol 296:H594-H615

102. Himeno Y, Sarai N, Matsuoka S, Noma A (2008) Ionic mechanisms underlying the positive chronotropy induced by beta1adrenergic stimulation in guinea pig sinoatrial node cells: a simulation study. J Physiol Sci 58:53-65

103. Himeno Y, Toyoda F, Satoh H, Amano A, Cha CY, Matsuura H, Noma A (2011) Minor contribution of cytosolic $\mathrm{Ca}^{2+}$ transients to the pacemaker rhythm in guinea pig sinoatrial node cells. Am J Physiol Heart Circ Physiol 300:H251-H261

104. Severi S, Fantini M, Charawi LA, DiFrancesco D (2012) An updated computational model of rabbit sinoatrial action potential to investigate the mechanisms of heart rate modulation. J Physiol 590:4483-4499

105. Takeuchi A, Matsuoka S (2014) Mitochondrial Na-Ca exchanger NCLX-mediated mitochondria-sarcoplasmic reticulum $\mathrm{Ca}$ crosstalk and cardiomyocyte automaticity. J Physiol Sci 64:S68

106. Guo J, Mitsuiye T, Noma A (1997) The sustained inward current in sino-atrial node cells of guinea-pig heart. Pflügers Arch 433:390-396

107. Jurkowitz MS, Brierley GP (1982) $\mathrm{H}^{+}$-dependent efflux of $\mathrm{Ca}^{2+}$ from heart mitochondria. J Bioenerg Biomembr 14:435-449 
108. Gunter KK, Zuscik MJ, Gunter TE (1991) The $\mathrm{Na}^{+}$-independent $\mathrm{Ca}^{2+}$ efflux mechanism of liver mitochondria is not a passive $\mathrm{Ca}^{2+} / 2 \mathrm{H}^{+}$exchanger. J Biol Chem 266:21640-21648

109. Jiang D, Zhao L, Clish CB, Clapham DE (2013) Letm1, the mitochondrial $\mathrm{Ca}^{2+} / \mathrm{H}^{+}$antiporter, is essential for normal glucose metabolism and alters brain function in Wolf-Hirschhorn syndrome. Proc Natl Acad Sci U S A 110:E2249-E2254

110. Bergemann AD, Cole F, Hirschhorn K (2005) The etiology of Wolf-Hirschhorn syndrome. Trends Genet 21:188-195
111. Nowikovsky K, Pozzan T, Rizzuto R, Scorrano L, Bernardi P (2012) Perspectives on: SGP symposium on mitochondrial physiology and medicine: the pathophysiology of LETM1. J Gen Physiol 139:445-454

112. Tsai MF, Jiang D, Zhao L, Clapham D, Miller C (2014) Functional reconstitution of the mitochondrial $\mathrm{Ca}^{2+} / \mathrm{H}^{+}$antiporter Letm1. J Gen Physiol 143:67-73 